\title{
Contemporary State of Unemployment of Bangladesh: A Critical Analysis
}

\author{
NARGIS SULTANA, ASSISTANT PROFESSOR \\ Department of Finance and Banking, Comilla University
}

\begin{abstract}
Unemployment is a serious intimidation towards the national development and economic growth of developing countries like Bangladesh. For developed countries, it is a blockade to the means of ensuring sustainable development. This work quintessence on the current situation of unemployment in Bangladesh. This study aims to sermon the current state of unemployment in an exploratory manner bearing in mind its detrimental magnitude on the economy of Bangladesh. The study also intentions to recommend some way out to get rid of the unemployment syndrome in a profligate and operative manner. Definitely 100 samples have been accumulated via purposive method for data collection purpose. Quantitative Method has been applied to the study and data has been collected through survey method from primary and secondary sources.
\end{abstract}

Keywords: Unemployment, Sustainable Development, Exploratory Manner, GDP Growth, Quantitative DOI: $10.7176 / \mathrm{EJBM} / 12-2-04$

Publication date: January $31^{\text {st }} 2020$

\section{Introduction}

Recent exploration displays that virtually one third of Bangladeshi youths are either unemployed or underemployed, leaving a hefty lump of budding labor of the developing country unutilized or underutilized (The Daily Star; July 11, 2014). The unemployed situation in Bangladesh has been fading particularly over the past two years, as per estimates by various research organizations. Whereas nearly 2 million new faces are linking the county's workforce annually, but there are 60.7 million faces that are either unemployed or underemployed. At the same time, over 2 lakhs foreign workers are working in the country mainly in garments, ICT and service sectors for which sufficient manpower is available in the country. During the year 2014-15, Bangladesh generated only 6 lakh jobs, 3 lakh annually on an average (The Bangladesh Chronicle; May 15, 2016). In the previous years, from 2003 to 2013, the annual average employment generation was 13.8 lakhs nationally, according to research output of the Centre for Policy Dialogue (CPD). These data signposts that how serious of an issue unemployment has become over the years. In a straightforward sense it may seem that the scarcity of job is the main reason behind unemployment. But it's not entirely true. There are so many factors that have a strong influence over unemployment. These factors must be identified so that we can take steps to reduce unemployment as much as possible. This issue of unemployment has become a barrier towards our development and there is no sign of improvement. I want to pave a way for overcoming this problem. That's why I want to conduct this research in such a way through which I can figure out the factors of unemployment, socio-economic structure of Bangladesh, administration and the job seekers role to reduce the rate of unemployment. This work of mine has a deep impact on sociological field. Through this work we can understand the current situation of unemployment in Bangladesh and thus get to know the socio-economic structure of Bangladesh which will lead us to the root of unemployment.

\section{Literature Review}

The rate of unemployment in the country, particularly youth unemployment is rising at a significant rate. Moreover, national rate of wage is still below the poverty bar. (UNNAYAN ONNESHAN, Bangladesh Economic Update, May 2017). Unemployment and poverty are two great problems in Bangladesh. If sufficient jobs are not generated unemployment problem will create many complex social and political problem. Moreover, educational institutions become the factories of producing huge number of unemployed people. So we should be careful to establish new educational intuitions specially universities. (Sarder Syed Ahmed \& Md. Rezaul Karim Khan 2017). Youth unemployment issue is crucial for sustainable development of Bangladesh. The youth unemployment has increased significantly over the years whereas the overall unemployment remained stable (CPD, 2016). It is expected that around one billion youth would enter the job market and only 40 percent of them would be able to get jobs in the next decade (ILO, 2015). The overall scenario implies that the youth unemployment has increased over the years. Similarly, the population has also grown. Though the population growth is fairly stable, on average 1.5 percent per year from 2000-2013 (ADB, 2016). A very important issue that plays a crucial role in development of the economies is the underutilization of its human capital i.e. unemployment. Unemployment is one of the major problems in almost all the countries of the world. It has been the most consistent problem which is faced by all industrially advanced as well as poor countries. Economic growth is a vital factor that affects the unemployment. (Mohammad Shafiur Rahman Chowdhury \& Md. Tanjil Hossain 2014). The main purpose of education in a developing country like Bangladesh is to train up and utilize properly the available human resources for the 
economic development of the country. The unemployed surplus educated manpower is not a resource, rather a drag on the economy of the country (A. Rashid Ahmed, Md. Ashraf Ali, and Kazi Saleh Ahmed 2015). In Bangladesh, almost all households depend on employment as their primary source of income. This is especially true for the poor households since the only abundant productive resource that the poor have is their own labor. Increasing employment opportunities and raising the returns to labor is therefore the most viable option to reduce poverty and meet the country's human development goals (Bangladesh Bank, 2015). Previous estimates of the effect of unemployment on crime commonly omit determinants of criminal behavior that vary with the business cycle, creating correlation between unemployment rates and the residuals in aggregate crime regressions (Steven Raphael \& Rudolf Winter-Ebmer). In Bangladesh, unemployment and underemployment problems arrive due to the lack of effective demand for labor (Murad S. M. Woahid, 2010-11). Unemployment of educated youth has, for quite some time, become a growing concern all over the world. The problem is particularly acute in the developing countries (A.K. Das, IIEP Occasional Paper). The new job creation in the rural sectors remains short of the number of people joining the labour force annually so that there is high rural unemployment, particularly underemployment (National Report on Sustainable Development, 2015). Nearly all of this unemployment is concentrated among young people who are looking for their first job. Unemployment duration is very long with typical spells lasting four years or more (William Dickens \& Kevin Lang). Unemployment is the result of the craze among the educated youth for 'white collar jobs'. Lack of education and vocational guidance facilities, are some of the other factors, which contribute to the problem of unemployment (Jitendra KUMAR Dixit, Sanjeev Kumar Gupta \& Harshit Gupta) The major problem related to absorbing ever growing population through providing them job opportunities (Dr. Habib-Ur-Rehman, 2015). The work has been carried out to figure out the reasons behind the huge amount of unemployment and this work will give a solid basis to work on the contemporary problems and get the maximum out it.

\section{Research Objectives}

- $\quad$ To treasure the major aspects behind unemployment and to suggest some measures to solve it.

- To understand the current situation of unemployment of our country.

- To know the responsibilities of the Government, the Private and Multi-national companies to minimize the situation.

\section{Methodology of the Study}

a) Data Sources: Data has been taken from two different sources

- Primary Sources: Undergraduate students, graduated students, job seekers, employed persons.

- Secondary Sources: Previous works, books, journals, newspapers, Bangladesh Bureau of Statistics and Websites etc.

b) Research Method: This study has been carried out through the Quantitative Research Method where attempt has been made to classify features, count them, construct statistical models.

c) Sampling Method: The Purposive sampling method has been used.

d) Sample Size: The sample size is 100 .

e) Data Collection Technique: The data of this study has been collected using the survey method. Data has been collected through questionnaire, direct conversation and internet (social network).

f) Data Analysis Plan: Basically statistical tools have been used to interpret observed variables. In this study most of the data are presented in a numerical manner. Some data has been interpreted in a non-numerical manner. The findings of the study will be used in both numerical and non-numerical manner.

\section{Unemployment Rate In Bangladesh:}

The unemployment rate in Bangladesh and other countries is defined as the number of unemployed people as percentage of the labour force. The labour force includes the people who are either employed or unemployed, i.e. who do not have a job but are actively looking for one. The unemployment rate of Bangladesh is given below last 5 years:

\begin{tabular}{|l|l|}
\hline Years & Rate \\
\hline 2014 & $4.2 \%$ \\
2015 & $4.2 \%$ \\
2016 & $4.1 \%$ \\
2017 & $4.2 \%$ \\
2018 & $4.2 \%$ \\
\hline
\end{tabular}




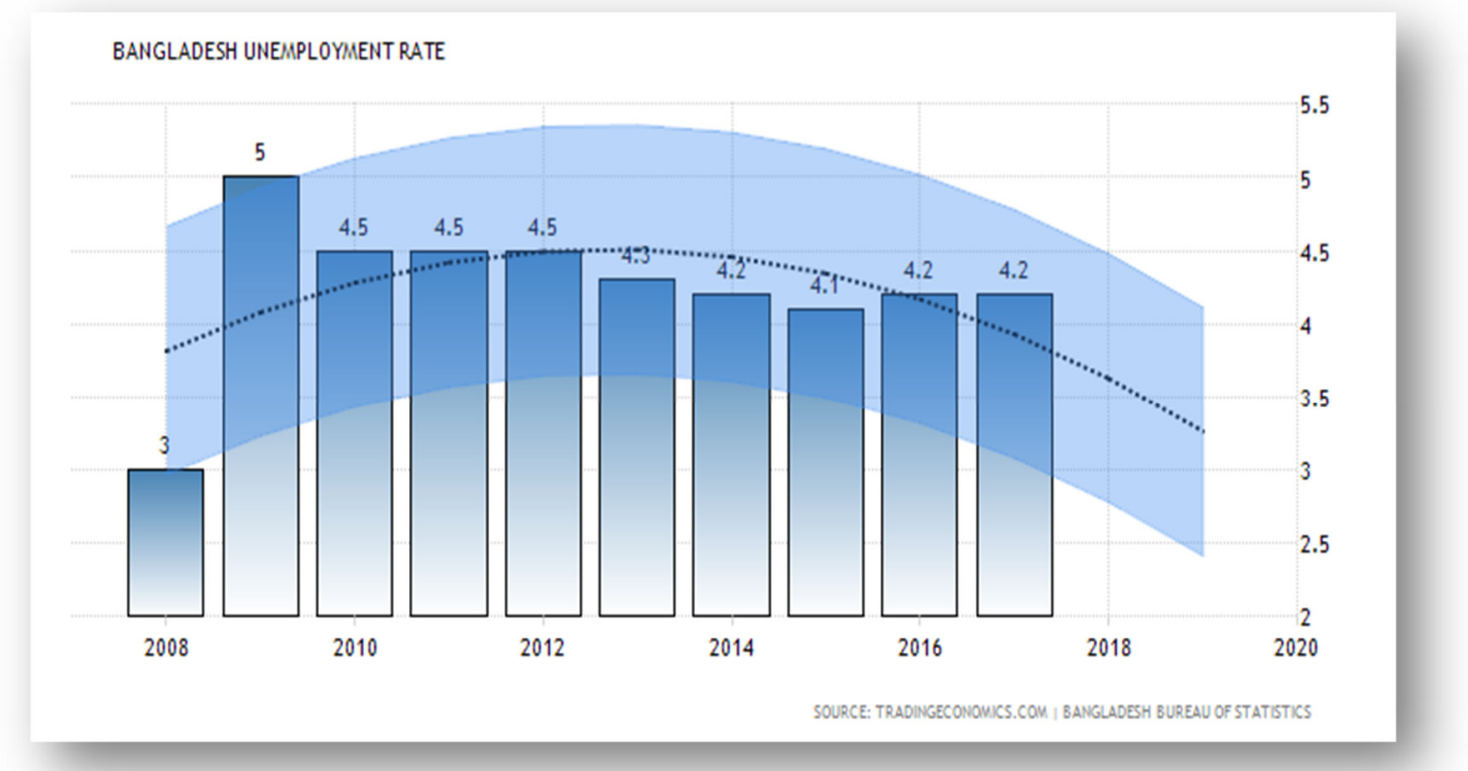

It has been revealed in the table that the unemployment rate infrequently declines below 4-5 percent even during boom times. Unemployment rate in Bangladesh persisted unmoved at 4.20 percent in 2017 from 4.20 percent in 2016. Unemployment rate in Bangladesh be an average of 3.85 percent from 1991 until 2017, feat an all-time high of 5.10 percent in 1997 and a record low of 2.20 percent in 1991.

\section{The Unemployment Rates among Demographic Area:}

\begin{tabular}{|l|c|c|c|c|}
\hline \multicolumn{1}{|c|}{ Country } & Last & $\begin{array}{c}\text { Previous } \\
(2017)\end{array}$ & Highest & Lowest \\
\hline Bangladesh & $4.20 \%$ & $4.20 \%$ & $5.1 \%$ & $2.20 \%$ \\
\hline Japan & $2.50 \%$ & $2.5 \%$ & $5.5 \%$ & $1 \%$ \\
\hline China & $3.89 \%$ & $3.9 \%$ & $4.3 \%$ & $3.89 \%$ \\
\hline Pakistan & $5.90 \%$ & $5.9 \%$ & $7.8 \%$ & $3.1 \%$ \\
\hline India & $(2016)$ & $(2015)$ & & \\
& $3.52 \%$ & $3.51 \%$ & $8.3 \%$ & $3.41 \%$ \\
\hline
\end{tabular}

Number of Educated Persons:

According to UNESCO, Bangladesh has an adult literacy rate of $72.76 \%$ while male literacy rate is $75.63 \%$, for females is $69.9 \%$.

Year
2016
2011
2007
2001
1991

Bangladesh Literacy Rate

$69.90 \%$

$46.74 \%$

$43.74 \%$

$40.82 \%$

$25.84 \%$

\section{Present Condition of Educated Person:}

According to a report published by BBS in $28^{\text {th }}$ May, 2017 ;

A. 1.4 million Labour force being added from December 2013 to June 2015 .

B. The total rate of unemployment is $4.2 \%$.

They are also saying that- 
No. of employed educated youth $87.9 \%$
No. of unemployed educated youth $12.1 \%$

And the report is also saying that 1.8 million educated people are underemployed.

Data Processing \& Analysis

Table 01: Age \& Gender Chart

\begin{tabular}{|c|c|c|c|c|}
\hline Age & Respondent & \% & Female & Male \\
\hline $\mathbf{1 9 - 2 1}$ & 12 & $12 \%$ & 9 & 3 \\
\hline $\mathbf{2 2 - 2 4}$ & 62 & $62 \%$ & 34 & 28 \\
\hline $\mathbf{2 5 - 2 7}$ & 16 & $16 \%$ & 5 & 11 \\
\hline $\mathbf{2 7 - 2 9}$ & 10 & $10 \%$ & 3 & 7 \\
\hline
\end{tabular}

Source: Field Survey

Table 01: Shows that $62 \%$ of the overall respondents are between ages $22-24$. Respondents of this portion are all undergraduates. Age 25 is the mark from where students start to become graduated and go out in the job field.

Figure 01: Respondents Academic Background

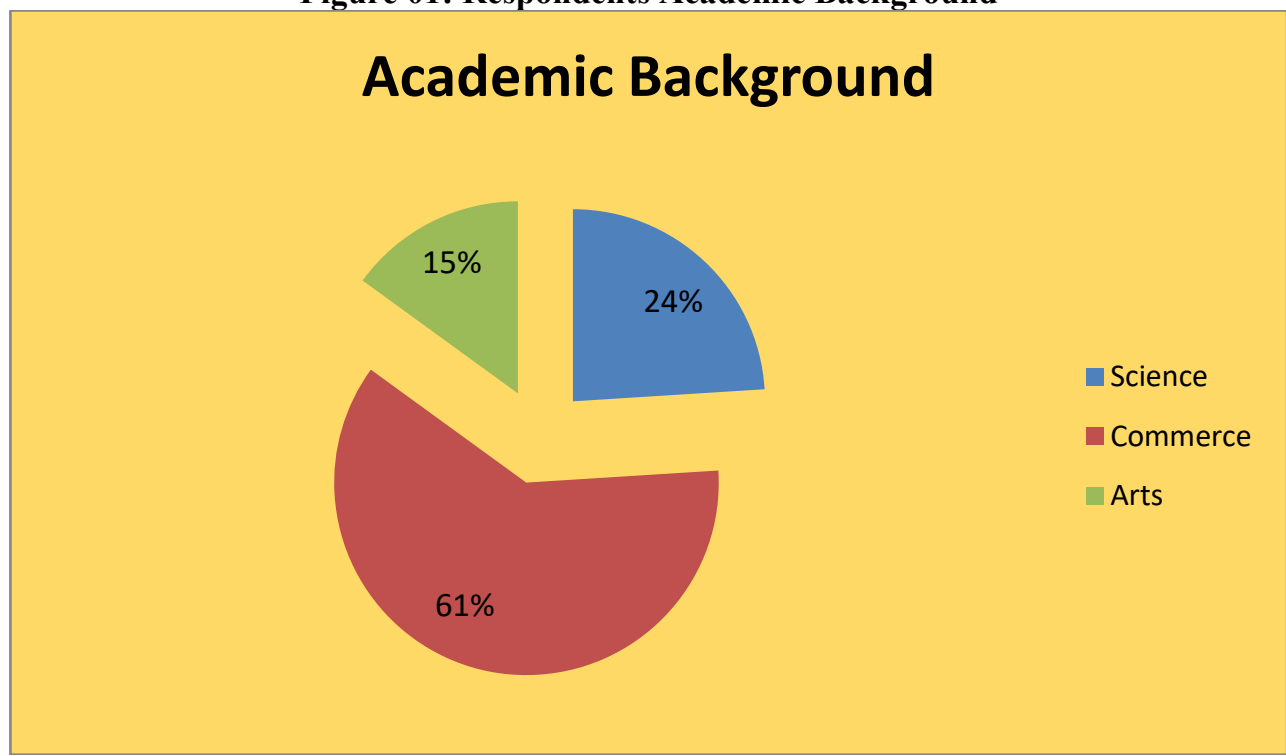

Figure 01: Suggests that $61 \%$ of the total sample is from Business Administration faculty. Data has been collected from various faculties so that we can get a comprehensive idea about the perception of students from different majors.

Table 02: Respondents Educational Status

\begin{tabular}{|c|c|c|}
\hline Education Qualification & Respondent & Percentage $(\%)$ \\
\hline Undergraduate & 75 & $77 \%$ \\
\hline Graduate & 15 & $15 \%$ \\
\hline Illiterate & 8 & $8 \%$ \\
\hline
\end{tabular}

Table 02: Represents the total number of undergraduate, graduate, illiterate persons who have participated in the study. As undergraduate students are more available than others, so $77 \%$ of the data has been collected from the students. 
Figure 02: Major Reasons Behind Unemployment

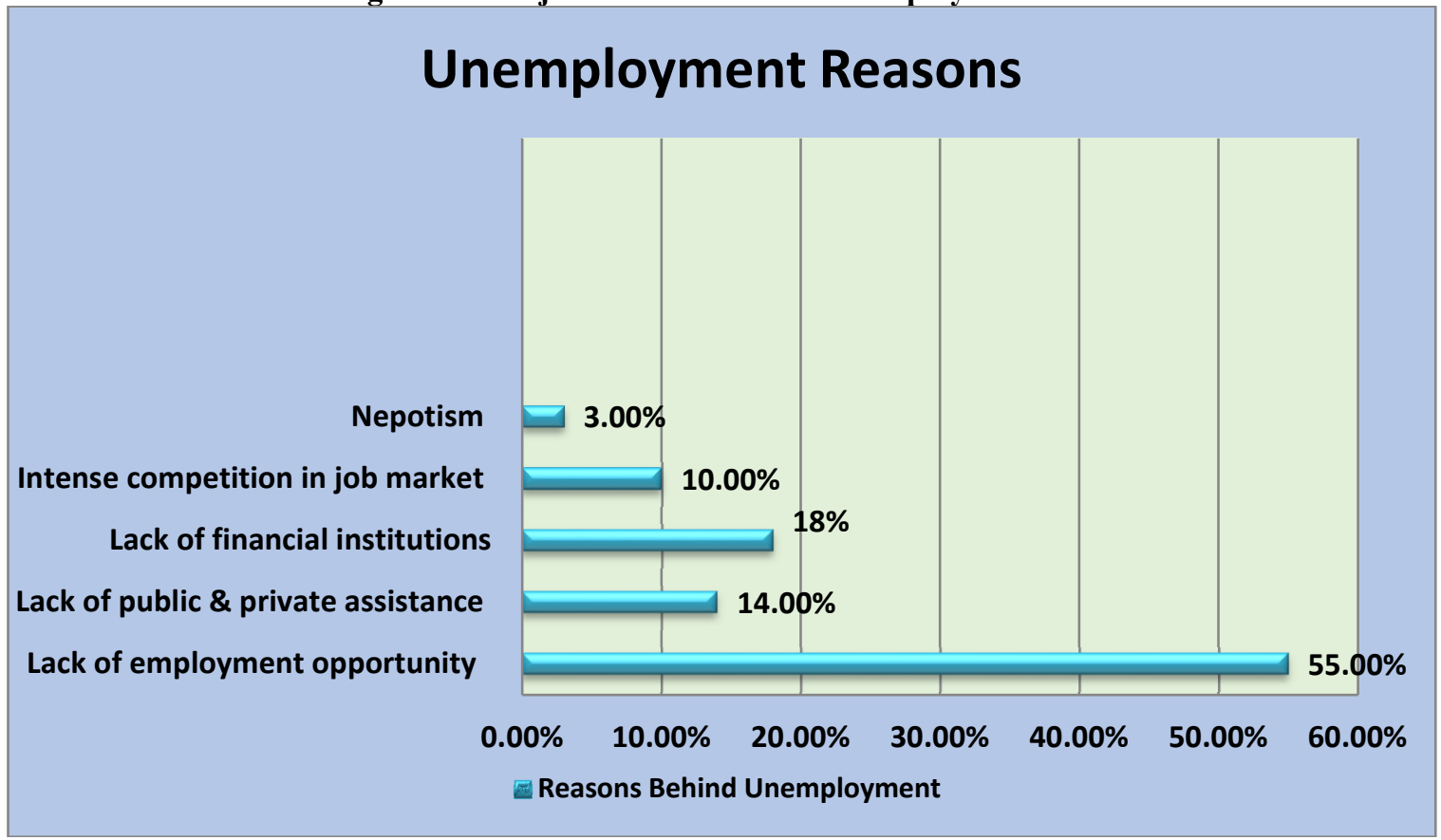

Source: Field Survey

Figure 02: Shows 55\% respondents think that "Lack of employment opportunity" is one of the major reasons of Bangladesh's unemployment. $18 \%$ of the respondents agreed to the fact "Lack of financial \& other institution" is causing unemployment.

Figure 3: Solution of Unemployment

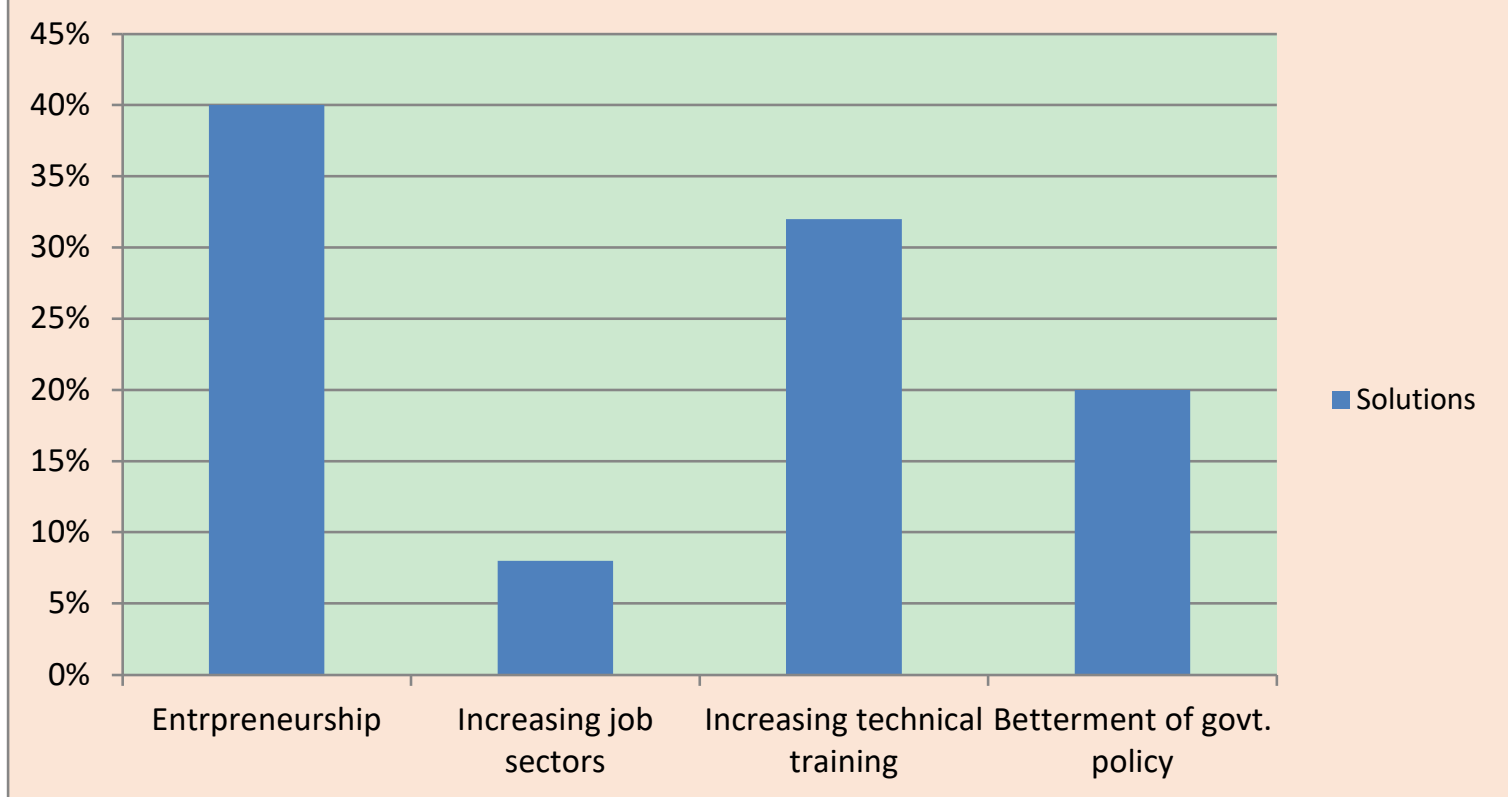

Figure 3: Shows the thoughts of respondents regarding the solution of their unemployment.40\% respondents believe that arrangement of entrepreneurship will be the possible solution of their unemployment. Some other respondents nearly $32 \%$ think that increasing technical training is the probable solution of their unemployment. 
Figure 4: Preferable Job Sector

\section{Preferable Sector}

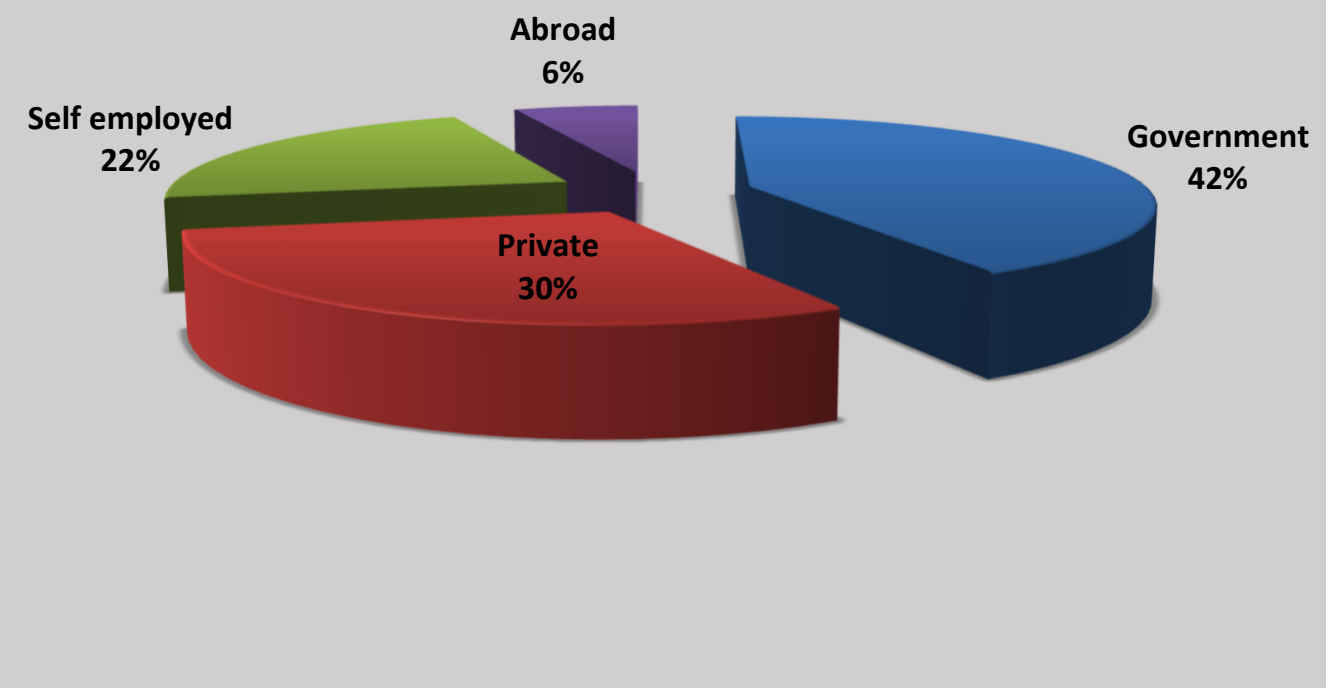

Figure 4: Shows that $42 \%$ respondent prefer government sector jobs more than other sector. The main reason behind this perception is that govt. job provide more prestige and more job facilities. $2^{\text {nd }}$ choice is govt. sector job. Besides, 30\% respondents prefer private sector job for higher salary and disciplinary practices.

Figure 05: Education System \& Job Market's Connection as a Major Unemployment Factor

\section{Blaming Education System \& Job Market's Connection}

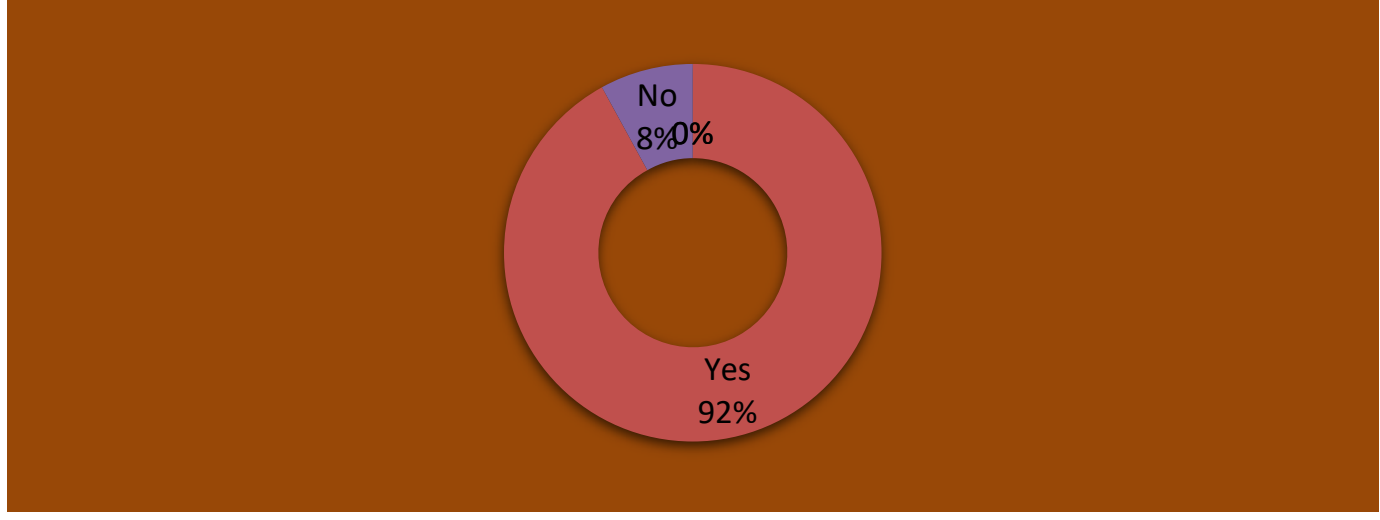

Source: Field Survey

Figure 05: Shows that 92 respondents believe the interconnection between our education system and job market is a major reason behind unemployment. And surprisingly this $84 \%$ respondent also suggests that education system should be developed and there should be a connection where "Study should not be for job, Job should be for study". This means a bigger subject specified job market. 
Figure 6: Disappointing Factor during Unemployment

\section{Dissapointing Factors}

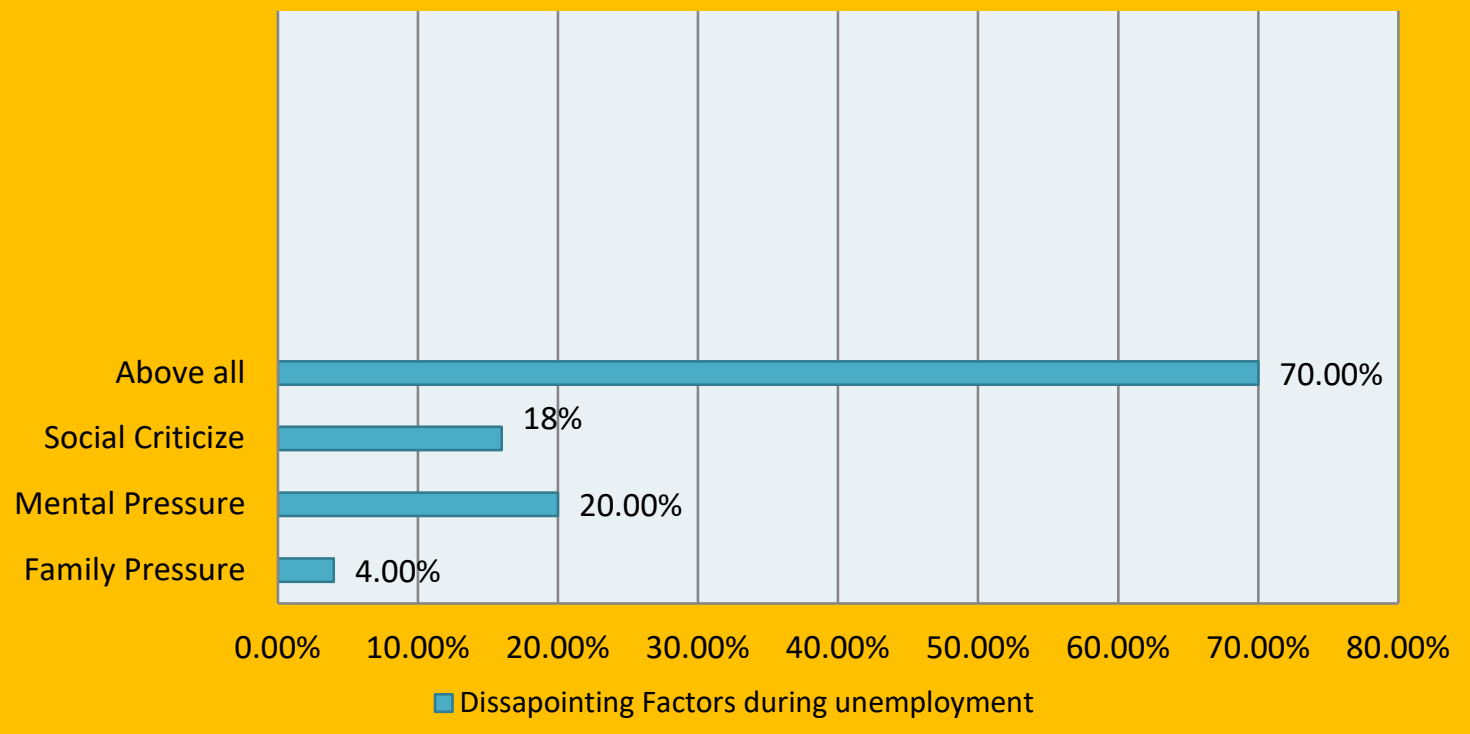

Source: Field Survey

Figure 6: Shows that $70 \%$ people become disappointed for not only a single factor but also all the factors like mental pressure, family pressure and social criticize as a whole that create an unfavorable situation for people during unemployment.

Figure 7: Relationship between crime and unemployment

\section{Crime \& Unemployment Relationship}

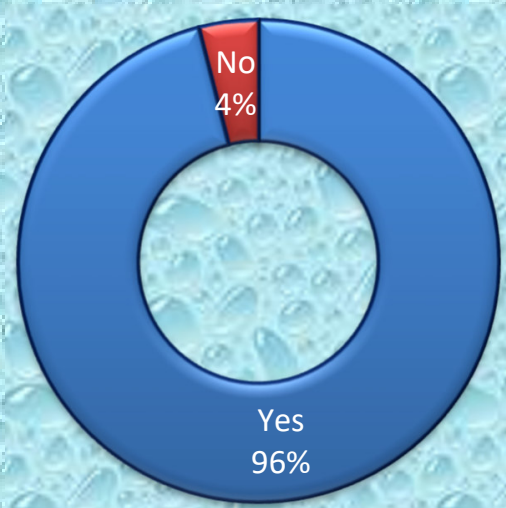

Figure 7: Shows that unemployment leads to excessive crime.96\% Respondents believe that there is a positive correlation between crime and unemployment. Frustration, depression, poverty etc. all are arisen from unemployment that lead to a person to engage in inhuman activities and to commit crime. 
Figure 8: Important Factors to Get Job

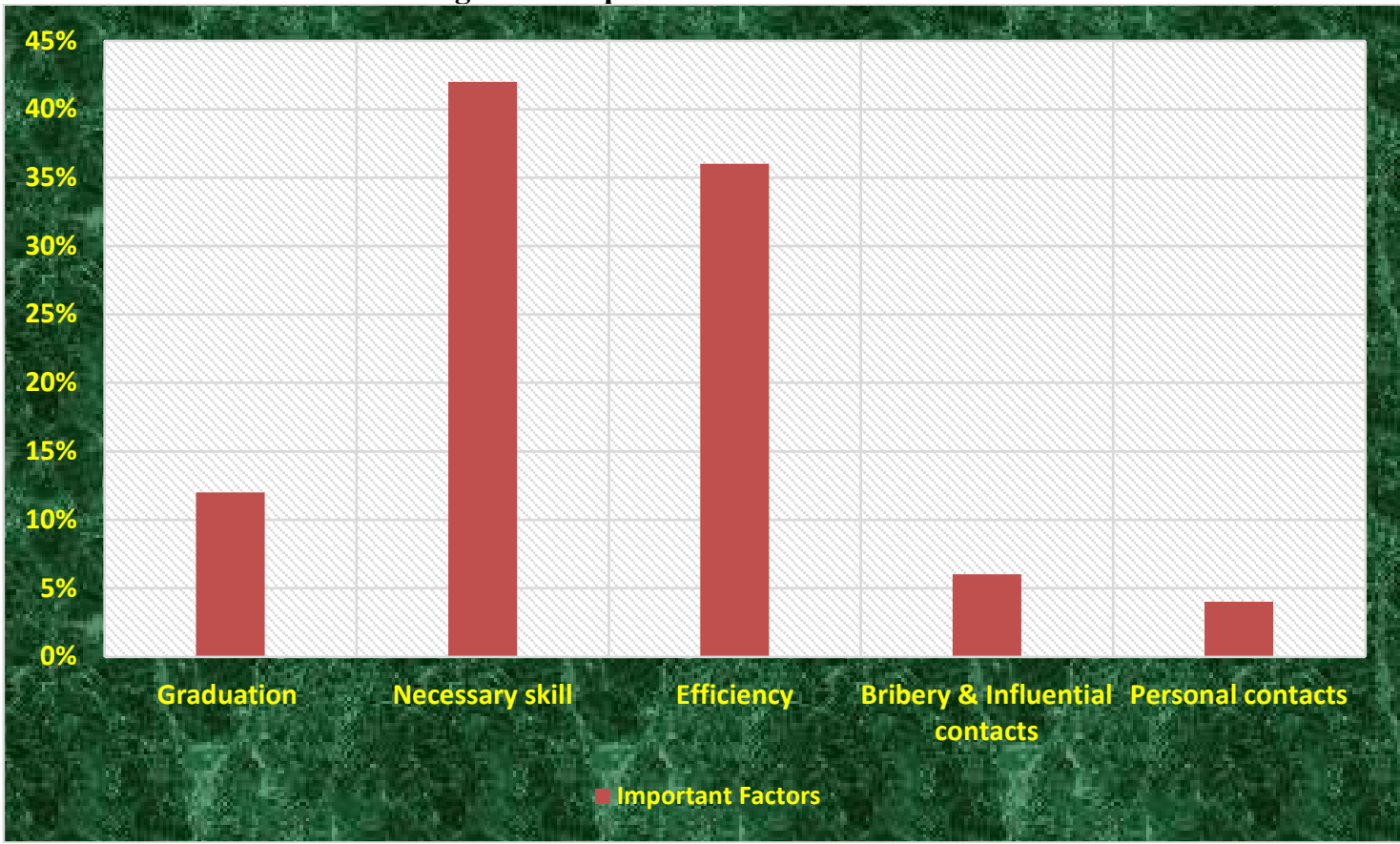

Figure 8: Represents the most important factors that are required to get a job. In this respect, $42 \%$ respondents think that necessary skill to do a particular work perfectly is the most important factor to get a job. A large portion of respondents nearly 36 percent marked the minimum level of efficiency as most important factor to get a job.

Figure 09: Unemployment Effect on the Economy of Bangladesh

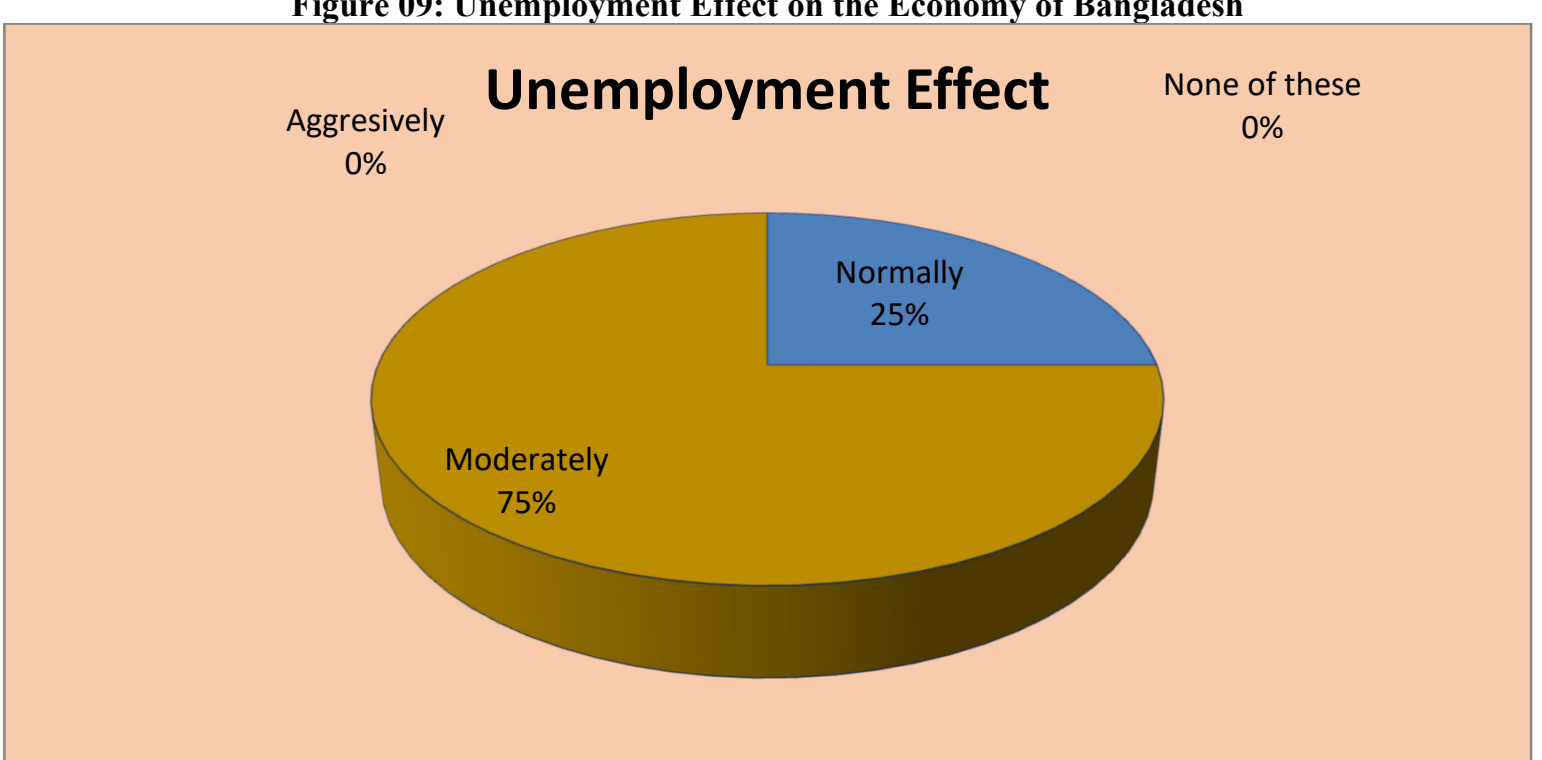

Figure 09: Unemployment always puts a negative impact on overall economy. Figure 09 represents that unemployment has a moderate effect on economy which is $75 \%$ according to the response of respondents. For ensuring a sound economy the reduction of unemployment is badly needed. 
Figure 10: Presumption of Job Opportunities In The Next Five Years

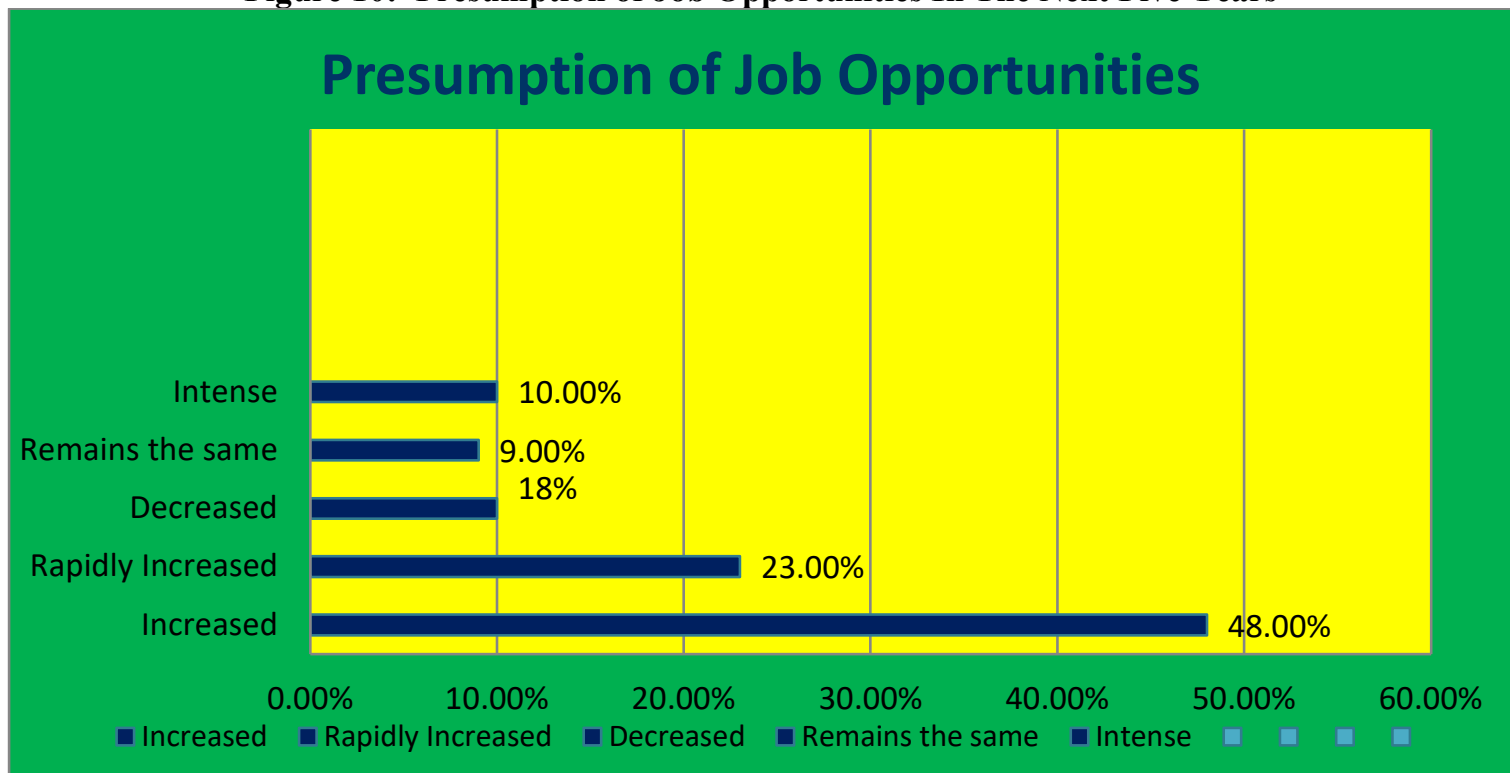

Figure 10: Shows the people's perceptions about the future job opportunities. Hope is that mysterious thing which can keep a person alive and provides confidence to go ahead at the time of difficulties \& gives a light to overcome the darkness of coming days. Here, respondents are also hopeful. About $48 \%$ respondents predict that the job opportunities will be increased in the next five years and the unemployment problem will be solved within shortest possible time.

Figure 11: Contribution of Different Parties for Overcoming Unemployment Problem

\section{Contribution For Overcoming Unemployment}

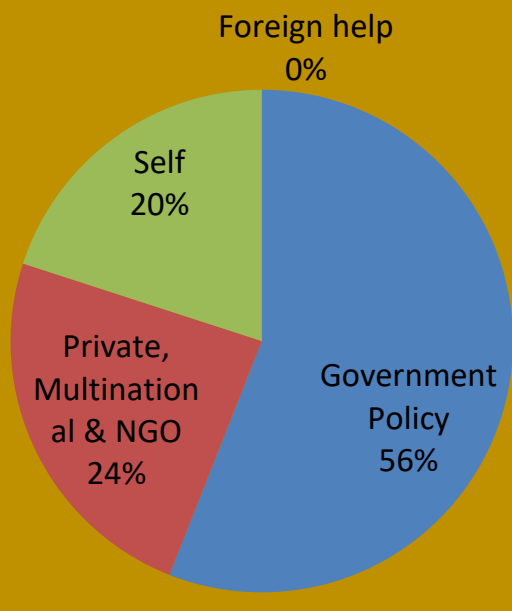

Figure11: Shows the percentages of major contributions of various sectors for overcoming unemployment. Good governance and a better govt. policy can reach to the optimum potential solution of a problem in the long run. $56 \%$ respondents give importance on govt. policy as a major contributor for overcoming unemployment.24\% respondents select the private, multinational and $\mathrm{NGO}$ as major contributor for overcoming unemployment.

\section{Reasons behind Unemployment}

Although, Bangladesh is a populous country but it is not being able to gain economic prosperity due to unemployment problems. Some common reasons of unemployment is highlighted below:

i. Over population: Bangladesh is an over populated country. Here we do not have enough job sectors in proportion to increasing population. So over population is one of the biggest reasons behind unemployment.

ii. Lack of job sectors: In our country we do not have enough job sector. Every year about 2.0 million youths coming out for employment. But they do not find jobs according to capacity. Lack of job 
opportunities are responsible for unemployment.

iii. Lack of proper knowledge about job market: Our country is not technologically advanced like many other countries in the world. In our country we see that most of the do not have proper knowledge about technology. So that, they do not have much knowledge about job markets.

iv. Lack of industrialization: Bangladesh is a developing country. Here most of the people lives below extreme poverty line. So, they do not want to take risk to invest their money in business or industrialization.

v. Lack of entrepreneurship: People always think of doing jobs in offices, banks, or other government jobs. But they do not think about their own business. Or they do not start new business just because of they do not want to take risk. So it is one of the biggest reasons of unemployment.

vi. High Interest Rates: For this reason entrepreneurs are not getting easy loans and job sectors is not explaining and unemployment is on the rise.

vii. Global Recession: Global recession is also responsible for unemployment. Economic activities are narrowing and overall demand for labor is decreasing as a result unemployment is occurring.

viii. Economic Reasons: Old industries close down like jute, coal mining and ship building are causing unemployment.

ix. Inclination to foreign products: Cars, computers, industries are import dependent and people also prefer this imported product as a result job sector opportunity is not expanding in those cases and unemployment is on a rise.

x. Government Economic Policy: If the Government spends less on big projects like roads, schools, hospitals, this means less people are needed to work and unemployment is created.

xi. New Technology: Computers and robots do the work that people need to do as a result unemployment rises. Also there are many other reasons like people aren't able to cope up with the latest technology.

xii. Nature of Production: Seasonal production characteristics is also responsible for unemployment. Industries as well as agricultural sectors requires less employees in slack seasons.

xiii. Nepotism: Due to nepotism, unqualified people are often recruited and these people are unable to add value to the economy and give birth to more unemployment,

xiv. Lack of financial institutions: In comparison with the growing population, the financial institutions aren't rising to fulfill the need of job needed by the unemployed people.

$\mathrm{xV}$. Intense competition in job market: Today many people fight for a single post. This issue is really alarming and acts as the major cause of unemployment.

xvi. Lack of public and private assistance: Lack of public and private assistance is found in creating employment opportunities for the rising population.

\section{Recommendations}

The purpose of the study is not only to explore problems but also to provide paths of getting rid of them. So the respondents are asked to suggest some ways through which unemployment can be reduced efficiently and effectively.

1. Avoiding power abuse.

2. Education system should be developed and there should be a connection where "Study should not be for job, Job should be for study.

3. Necessary skills to do a particular work perfectly is the most important factor to get a job.

4. Avoiding nepotism.

5. Mental pressure, family pressure and social criticism should be minimized.

6. Proper management of regulation.

7. Increase transparency in recruitment system.

8. Making a more efficient education system that can provide more job opportunities to the graduates.

9. Organize programs and generate ideas through which young entrepreneurship can be encouraged. Entrepreneurship will be the possible solution of unemployment.

10. Creating more job fields and take steps to inspire young generation think creatively and not to run after some generalized jobs.

11. It is the responsibility of everyone who participates in a functional society.

12. Unemployment is the responsibility of the individual. We must want to be employed. But some people just do not want to be employed.

13. Unemployment is the moral responsibility of the employer but not the economic responsibility of said employer. The employer is technically first and foremost responsible to stakeholder to produce a profit or an increase in value of the enterprise.

14. Unemployment is the responsibility of the currently employed to try and do their job to the best of their ability, so their organization does not have to create unemployment. 
15. To bring change in industrial technique.

16. Expansion of Employment exchanges.

17. More assistance to self-employed people.

18. Full and more productive employment.

19. Increase in Production.

20. More importance to employment programs.

21. High rate of capital formation.

22. Encourage industries in co-operative sector.

23. Decentralization of industrial activity.

24. Population control.

25. More government job can be created as people are getting inspired by those jobs.

Here are some recommendations to the unemployed of getting themselves out of the label of unemployed.

i. Try to become self-employed; e.g. Small farming, Fishery, Freelancing, Programming, Handcraft, Small business etc.

ii. Become specialized in IT

iii. Ready oneself to fight harder.

iv. Figure out what one is best at and then keep on doing that no matter what. There will be some ups and downs, lots of downs probably. But one should never give up.

v. Creating one's own path and not to always follow others footsteps.

\section{Conclusion}

Unemployment is a like cancer to a country's development. It is a huge waste to the human resource. Bangladesh has a huge population but the matter of regret is that most of the people are not a resource. Because of rising inhabitants and comparatively minor magnitude of the economy employment formation is a perplexing undertaking for Bangladesh. Nonetheless, the progression of the economy has not been escorted by sufficient employment creation and the number of jobless people has augmented over the years. One of the inspiring improvements in the employment scenario of the economy has been the proliferation of female involvement in the labor force. The good news is that the Govt. of our country is trying to mitigate the rate of unemployment. To exterminate unemployment, the present Govt. assured to create employment opportunities for 12.8 million people in the next five years. A thousand youths from each upazila will get employment opportunities outside the country as well. Enrichment of economic growth should be at the centre of an employment policy, which will be entwined with the ultimate aim of poverty lessening through employment generation. Conversely, for Bangladesh the major stimulus for improved employment has to come from the private sector. Enhancing growth and employment creation in Bangladesh will of course necessitate deletion of obstacles such as infrastructural tailbacks, institutional faintness and political uncertainty. So, we are hopeful that the job opportunities will be increased in the next five years and the unemployment problem will be downcast within shortest possible time.

\section{References}

- Molla, Mohammad Al-Masum, and Wasim Bin Habib. "26 Lakh Jobless.” The Daily Star, 28 May 2017, retrieved form www.thedailystar.net/frontpage/26-lakh-youths-jobless-1411804.

- “Bangladesh Unemployment Rate, 1991-2018, Data Chart Calendar.” Haiti Exports, 2008-2018, Data Chart Calendar Forecast News, tradingeconomics.com/Bangladesh/un-employment-rate.

- "Unemployment the Biggest Challenge." The Daily Star, 7 Mar. 2015, retrieved form www.thedailystar.net/unemployment-the-biggest-challenge-32823.

- "Unemployment Reaching a Critical Level in Bangladesh." The Bangladesh Chronicle, 15 May 2016, retrieved form bangladeshchronicle.net/2016/05/unemployment-reaching-a-critical-level-in-bangladesh/.

- Aaronson, et al. "What Is Behind the Rise in Long-Term Unemployment?" Canadian Social Science, Canadian Research \& Development Center of Sciences and Cultures; Canadian Academy of Oriental and Occidental Culture, 22 June 2010, retrieved form www.questia.com/library/journal/1G1-238652482/what-isbehind-the-rise-in-long-term-unemployment.

- "Unemployment Problem In Bangladesh.”Wealthwiz, 29 July 2016, retrieved form wealthwiz.co/unemployment-problem-in-bangladesh/.

- "Unemployment a Big Problem for Bangladesh." World Population Prospects: The 2017 Revision, Theindependentbd.com, retrieved form www.theindependentbd.com/print-version/details/141035.

- "Bangladesh Unemployment Rate, Economic Indicators, CEIC.” Japan Annual House

hold Incomeper Capita, Economic Indicators, retrieved form www.ceicdata.com/en/indicator/bangladesh/unemployment-rate.

- Asadullah, M. Niaz. “Is Graduate Unemployment Rate Really 47\%?” The Daily Star, 7 Mar. 2015, retrieved 
form www.thedailystar.net/is-graduate-unemployment-rate-really-47-22302?browserpush=true.

- "BBS Survey Finds 4.18 per Cent of Workforce Unemployed." World Population Pros-pects: The 2017 Revision, Theindependentbd.com, www.theindependentbd.com-/arcprint/details/96759/2017-05-29.

- "Bangladesh - Unemployment Rate 2007 to 2017 | Statistic." Statista, www.statista.com/statistics/808225/unemployment-rate-in-bangladesh/ 